IFN Working Paper No. 688, 2007

\title{
The Political Economy of Entrepreneurship: An Introduction
}

\author{
Robin Douhan and Magnus Henrekson
}




\title{
THE POLITICAL ECONOMY OF ENTREPRENEURSHIP: AN INTRODUCTION
}

\author{
Robin Douhan ${ }^{1,2}$ and Magnus Henrekson ${ }^{2}$
}

January 3, 2007

\begin{abstract}
In this introductory chapter to a collective volume dealing with the political economy of entrepreneurship," we argue, based on a suggested unifying framework, that political economy is a fruitful approach to entrepreneurship. The importance of institutions in structuring such an analysis is also emphasized. The introduction also introduces the selected articles and puts them in context. Vital functions of the capitalist economy are ascribed to the productive entrepreneur, but the selected articles also show that the social value of entrepreneurship must be evaluated as it is realized. Three facets of entrepreneurship are claimed to be of particular importance from a political economy perspective:

(i) Entrepreneurship is dynamic in the sense that it adapts to the politically determined institutional framework within which it acts. Under propitious circumstances, it can be a powerful engine of growth, but it can also be channelled in unproductive and destructive directions.

(ii) Entrepreneurship enters directly into the political system. The close connection to property rights constitutes a link between entrepreneurship and private versus public ownership and redistribution. Under unfavourable institutional circumstances, rent-seeking and predatory entrepreneurship, via the political system, offer greater profit opportunities than the market.

(iii) A political economy approach is necessary in order to understand how the political system shapes the institutional setup. Here, it is emphasized that the distribution of political power is partly determined by economic wealth. Hence, it is relevant to broaden the analysis to the effects on wealth creation and wealth redistribution stemming from entrepreneurial activity.
\end{abstract}

JEL Codes: H32; L5; L25; M13; O31; P14.

Keywords: Entrepreneurship; Industrial Policy; Innovation, Property Rights; Regulation; Selfemployment.

${ }^{1}$ Department of Economics
Uppsala University
Box 513
SE-751 20 Uppsala
Phone: +46-18-471 1590
Fax: +46-18-471 1478
e-mail: robin.douhan@nek.uu.se

\author{
${ }^{2}$ Research Institute of Industrial \\ Economics \\ Box 55665 \\ SE-102 15 Stockholm \\ Phone: +46-8-665 4502 \\ Fax: +46-8-665 4599 \\ e-mail: magnus.henrekson@riie.se
}

\footnotetext{
${ }^{*}$ The International Library of Entrepreneurship Series: The Political Economy of Entrepreneurship, edited by Magnus Henrekson and Robin Douhan (Northampton, UK: Edward Elgar, forthcoming 2007).
} 


\section{INTRODUCTION AND FRAMEWORK}

The wide array of definitions of entrepreneurship in the literature all entail different focuses such as risk taking, innovation or responsiveness to opportunities. To approach research in entrepreneurship is therefore to approach a seemingly fragmented research field. Still, the contributions in this diverse field have at least one noteworthy trait in common: Although many theorists have set out from one of these definitions, they have, at the same time, assumed the distinguishing characteristic of their choice to be at the core of the capitalist economy. More importantly, this has often been done in order to highlight a crucial distinction vis-à-vis a socialist alternative. A prime example is Joseph Schumpeter's (1942) analysis of the (inexorable) demise of capitalism in Capitalism, Socialism and Democracy and how this is fundamentally linked to the waning importance of entrepreneurship. Even more striking is how capitalism and entrepreneurship are intertwined in the Austrian school of economics, e.g. in Israel Kirzner's thinking. These influential examples illustrate how the political-economic aspects are at the centre of the economic analysis of entrepreneurship.

As pointed out by Schumpeter in one of the texts we have selected for this Handbook, analysing the subject of political economy of entrepreneurship is by no means straightforward. Adding the famously illusive concept of the entrepreneur to the broad and somewhat vague notion of political economy brings forth a number of problematic issues of delineation and definition. The approach we have found to yield most structure to the analysis is to give institutions a central role.

The purpose of this introduction is to present a unifying framework of the political economy of entrepreneurship. In this way, we argue that political economy is a fruitful approach to entrepreneurship. We also emphasize the importance of the notion of institutions in structuring such an analysis. This introduction also serves the purpose of introducing the selected articles and putting them in context.

The framework for analysing the political economy of entrepreneurship is laid out in figure 1. It is essential to this illustration and to our approach that we can only evaluate the entrepreneur (E) and entrepreneurial behaviour given the institutional context. ${ }^{1}$ When viewed as a resource, the entrepreneur is, in this respect, very different from the usual capital and labour resources. Moreover, as we will see, once we consider the institutional setup, there is no guarantee that a potential entrepreneur will actually put his or her time and effort to (socially) productive use.

Entrepreneurial activity affects the extent to which the economy is able to adapt to changing circumstances and renew itself through innovations. These two aspects correspond to the equilibrating function described by Kirzner and the Schumpeterian disequilibrating entrepreneur, respectively. ${ }^{2}$ In practice, these functions are outcomes of new and different ways of combining resources in the form of human capital $(\mathrm{H})$, physical capital $(\mathrm{K})$ and labour $(\mathrm{L})$ resources (for simplicity, we abstract from intermediate inputs and raw materials). ${ }^{3}$ Metaphorically, capital and

\footnotetext{
${ }^{1}$ Institutions have moved to the fore of mainstream explanations for economic performance, especially in the longer term. See, for example, North and Weingast (1989), Rodrik et al. (2004) and Acemoglou et al. (2005).

${ }^{2}$ See Baumol (2005) and Yu (2001) for a discussion of these two aspects and how they can be brought together in the same system. See also Kirzner (1999) for a critical assessment of this difference.

${ }^{3}$ In this respect, the model laid out in figure 1 has obvious similarities to Leibenstein (1968). He emphasizes the entrepreneurial function of bringing together different factors of production. Moreover, he points to two entrepreneurial functions in the development process: (i) introducing new techniques,
} 
labour can be said to be put into more or less fertile soil, which allows for greater or less dynamism. In the limit, where the entrepreneur is removed from the analysis (or, for that matter, from the economic reality), this environment congeals, resulting in a static economy. This is the first link in the system, which is represented by (1) in figure 1.

Together, the equilibrating and disequilibrating forces, capital in its human and physical form as well as labour, determine the economic outcome. Beside possible growth, the economic outcome also involves the distribution of economic resources. This brings us to the next two links in the system, denoted by (2) and (4). First, since economic strength can be translated into political power, it entails an ability to influence the political system, link (4). Second, in the context of entrepreneurship, political entrepreneurship provides a direct link between entrepreneurship and the political system, link (2).

The final link (3) in this system is how the political system determines the formal institutions, and thereby also the pertinent institutions, i.e. the institutions that are relevant for entrepreneurial activity. It should be noted that institutions also directly affect various aspects of the resources, which is illustrated by a dotted arrow. Our focus here on certain pertinent institutions is due to pedagogical considerations and is made to facilitate a structured analysis of the role of the entrepreneur. It does not imply that we deny the relevance of other institutions and causal linkages.

Figure 1 Entrepreneurship in a Growth System.

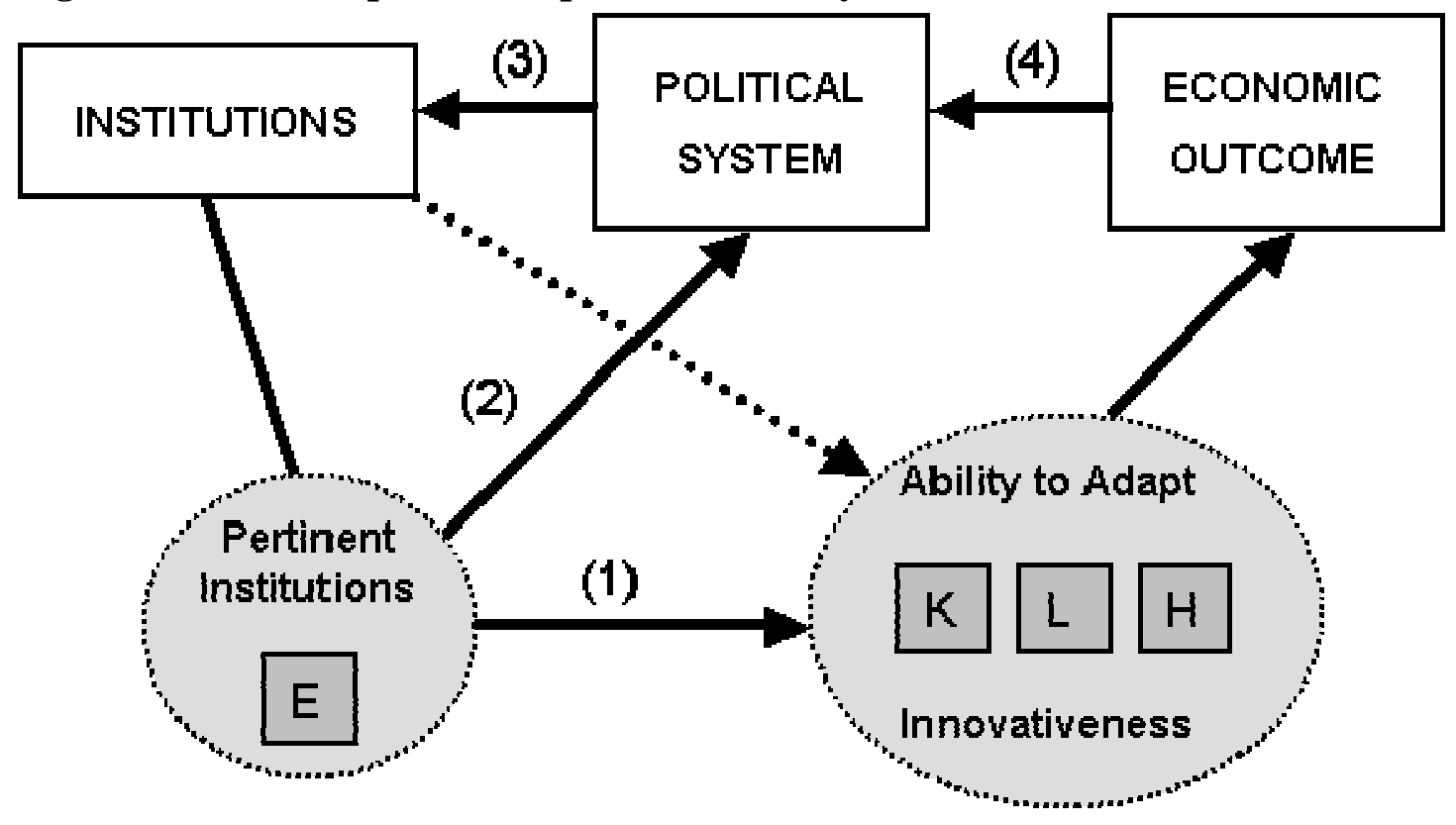

Link (1): Entrepreneurship in its institutional context

The emphasis on the rules of the game is primarily due to Baumol $(1990,1993)$, who stressed that entrepreneurship can take on many different forms - some of which are productive, some unproductive and some even destructive. On the surface, the logic is deceptively simple. If the rules are such that it is beneficial for the individual to spend

commodities, materials, markets or organizational form and (ii) creating new economic capacity. These roughly correspond to (i) the innovativeness and (ii) the ability to adapt in figure 1. 
entrepreneurial effort on circumventing them, she will do so rather than using the rules to reduce uncertainty and enhance contract quality. In this case, the outcome is expected to be one where corruption and rent-seeking prevail over productive entrepreneurship.

In reality, the interaction between various dimensions of the institutional setup and the type and level of entrepreneurial activity is highly complex and therefore difficult to disentangle. To give a hint of the complexity, consider table 1 below, where different motives for starting a business are given. The top row gives society's first-best alternatives. Here, an entrepreneurial business is started because it provides the best vehicle for pursuing a business opportunity. Other, strictly speaking nonentrepreneurial, motives are to give the owner the opportunity to pursue a certain lifestyle, earn his/her living independently or facilitate the organization of certain projects best pursued as an independent firm but without being an entrepreneurial venture.

In a second-best outcome, the entrepreneurial motives arise because of various obstacles barring the optimal arrangements. Entrepreneurship here provides a means of circumventing obstacles that could emanate either from policy failures or from within the private sector. For instance, inferior management and business organizations may prevent an intrapreneur from introducing and reaping the rewards from his or her ideas. Or the tax legislation could make the use of stock option incentives to encourage intrapreneurship prohibitively expensive. Other incentives are also at work; becoming self-employed can, for instance, be a way of escaping excessive labour regulation or, in a more general sense, achieving the kind of flexibility that is obstructed by regulations. These kinds of effects can probably explain the, seemingly paradoxical, high levels of small-business activity observed in many countries with extensive government involvement.

In the most unfavourable case, the incentives are distorted towards exploiting the business opportunities arising from the regulation itself. Entrepreneurial incentives to start a business are geared towards exploiting tax breaks and subsidies rather than creating value. Sidestepping or reducing the impact of taxes and other legislation are also the prime motives for non-entrepreneurial businesses under this kind of regime.

In a recent survey of the development status of Romania, Coyne and Leeson (2004:243) wrote: "There are two ways to interpret the situation in Romania. The standard interpretation, reflected in reports by development agencies, is that there are high barriers to entrepreneurs and, hence, a shortage of entrepreneurship. Another interpretation is that entrepreneurship in Romania is flourishing. The key is the distinction we made between productive, unproductive and evasive entrepreneurship. Productive entrepreneurship is currently stagnant in Romania. Unproductive and evasive entrepreneurship, on the other hand, are alive and well”. This illustrates the importance of conducting the analysis through the lens of the institutional setup. Few, if any, societies have managed to completely quell the individual's innovativeness and pursuit of personal gains. The key difference is whether and to what extent they have managed to gain rather than lose from these human traits. 
Table 1 Self-employment - A Typography.

\begin{tabular}{lll}
\hline & Entrepreneurial & Non-entrepreneurial \\
\hline First best & $\begin{array}{l}\text { 1. Pursue a business } \\
\text { opportunity most suitably } \\
\text { pursued in a new firm }\end{array}$ & $\begin{array}{l}\text { 1. Seeking independence, a } \\
\text { certain life style etc. }\end{array}$ \\
& & $\begin{array}{l}\text { 2. Local service production; } \\
\text { working in networks in } \\
\text { temporary projects }\end{array}$ \\
Second best & $\begin{array}{l}\text { 1. Necessity entrepreneurship } \\
\text { 2. Inferior management by } \\
\text { current employer bars efficient } \\
\text { intrapreneurship }\end{array}$ & $\begin{array}{l}\text { 1. Safety valve to circumvent } \\
\text { excessive labour market } \\
\text { regulations }\end{array}$ \\
& $\begin{array}{l}\text { 3. Mechanism to escape the } \\
\text { effect of discrimination or the } \\
\text { lack of social capital for } \\
\text { marginal groups }\end{array}$ & $\begin{array}{l}\text { 2. Means to achieve flexibility } \\
\text { hindered by other regulations }\end{array}$ \\
& $\begin{array}{l}\text { 3. Mechanism to escape the } \\
\text { effect of discrimination or the } \\
\text { lack of social capital for } \\
\text { marginal groups }\end{array}$ \\
& $\begin{array}{l}\text { 1. Set up a business to exploit } \\
\text { subsidies and tax breaks rather } \\
\text { than create value for customers }\end{array}$ & $\begin{array}{l}\text { 1. Transform consumption } \\
\text { expenditure into tax deductible } \\
\text { business costs }\end{array}$ \\
& $\begin{array}{l}\text { 2. Fraudulence, where revenue } \\
\text { is partly unreported etc. }\end{array}$ \\
\hline
\end{tabular}

Note: The table lists the major motives for self-employment. Entrepreneurial self-employment may partly be pursued in search of independence, and fraudulent rent-seeking may also be entrepreneurial.

Links (2) and (4): Influence on the political system

If link (1) accounts for the influence of institutions on entrepreneurship, the two remaining links in the system, (2) and (4), together with (3), can be said to describe the reverse causality.

There is a great deal of inertia in most political systems. Many of the pertinent institutions are incarnated in written laws and documents, organizations and bureaucracies and not the least in individuals and social networks. All these entities take time to change, but it would be a mistake to infer that changes in these mechanisms can be omitted from the analysis. Links (2) and (4) highlight two reasons why this is especially true in an analysis focusing on entrepreneurship.

First (4), modern history gives us many examples where successful entrepreneurship has resulted in exceptional accumulation of private wealth. In the context of political economy, we cannot neglect the political power that can be wielded with such fortunes. Beyond the individual, this also has the potential of making entrepreneurs influential as a group.

Second (2), entrepreneurs are, by (at least most) definition, active in shaping their environment. Under the most unfavourable circumstances, current institutions make it profitable for entrepreneurs to direct their energy and talent to rent extraction. Instead of engaging in productive venturing, entrepreneurs act so as to bring about new legislation and institutions, designed to bolster their position. This can cement old structures that are detrimental to growth. But the opposite may, of course, also 
happen. Entrepreneurs can take part in politics and with their insight into current and future development, contribute to a more adaptive institutional setup.

Link (3): Politically induced change of institutions

Institutions are commonly referred to as the rules of the game that govern the conduct of economic activity and that, in Baumol's (1990) words, shape "the social structure of payoffs". In a political context, it is useful to classify various rules depending on who sets them. For our purposes, the most obvious agent is the government, but there are also other important agents such as labour unions and lobbying groups.

These are agents that actively try to influence and change existing institutions. This excludes rules that appear as side effects, such as many of the informal rules commonly called norms or values, which arise within a specific ethnic group, cultural community or a smaller group of people with frequent social interaction (Granovetter, 1995). To the extent that these groups do not actively and consciously try to shape their institutional environment, they will not be included. It should be noted that with respect to entrepreneurship more generally, this selection is too restrictive and would, for instance, neglect the important aspect of social attitude toward entrepreneurship qua an individualistic venture (Hofstede, 2001). For instance, in Schumpeter (1934), a central argument revolves around how the entrepreneur broke away from old routines and how this required special powers in order to endure social resistance emanating from entrenched values.

\section{ORGANIZATION OF THE HANDBOOK}

The various parts of the Handbook each deal with a topic that is an integral part of the framework presented here. The organization is easily explained by pointing at the place of each part in figure 1 .

○ Part I collects articles where the approach is overarching and which together serve to explain the design of figure 1 as a whole.

o Parts II to V deal with how various institutions affect entrepreneurial decisions, link (1)

o Part VI deals with link (2), and how the notion of political entrepreneurship implies a direct link from entrepreneurship to the political system.

○ Parts VII and VIII deal with questions pertaining to how the institutions are shaped by the political system. Hence, they belong to link (3).

o Part IX is best characterized as belonging to link (4) which leads from economic outcome to the political system.

- The last two parts, $\mathrm{X}$ and $\mathrm{XI}$, deal with questions that are best organized under link (1). 


\section{REFERENCES}

Acemoglu, Daron, Simon Johnson and James A. Robinson (2005), 'Institutions as the Fundamental Cause of Long-run Growth', in Aghion, P. and S. Durlauf (eds.), Handbook of Economic Growth, Amsterdam: North-Holland.

Baumol, William J. (1990), 'Entrepreneurship: Productive, Unproductive, and Destructive’, Journal of Political Economy, 98(5), 893-921.

Baumol, William J. (1993), Entrepreneurship, Management and the Structure of Payoffs, Cambridge, MA: MIT Press.

Baumol, William J. (2005), 'Entrepreneurship and Invention: Toward Restoration into Microeconomic Value Theory’, mimeo, New York University.

Coyne, Christopher J. and Peter T. Leeson (2004), ‘The Plight of Underdeveloped Countries', Cato Journal, 24(3), 235-249.

Granovetter, Mark (1995), ‘The Economic Sociology of Firms and Entrepreneurs’, in Portes, A. (ed.) The Economic Sociology of Immigration, New York: Russell Sage Foundation.

Hofstede, Geert (2001), Culture’s Consequences ( $2^{\text {nd }}$ ed), Thousand Oaks, CA: Sage Publications.

Kirzner, Israel M. (1999), 'Creativity and/or Alertness: A Reconsideration of the Schumpeterian Entrepreneur', Review of Austrian Economics, 11(1/2), 5-17.

Leibenstein, Harvey (1968), 'Entrepreneurship and Development’, American Economic Review, 58(2), 72-83.

North, Douglass C. and Barry R. Weingast (1989), 'Constitutions and Commitment: Evolution of Institutions Governing Public Choice in Seventeenth Century England', Journal of Economic History, 49(4), 803-832.

Rodrik, Dani, Arvind Subramanian and Francesco Trebbi (2004), 'Institutions Rule: the Primacy of Institutions over Geography and Integration in Economic Development’, Journal of Economic Growth, 9(2), 131-165.

Schumpeter, Joseph A. (1934), The Theory of Economic Development, Cambridge, MA: Harvard University Press.

Schumpeter, Joseph A. (1942), Capitalism, Socialism and Democracy, New York: George Allen \& Unwin.

Yu, Tony Fu-Lai (2001), ‘An Entrepreneurial Perspective of Institutional Change’, Constitutional Political Economy, 12(3), 217-36. 


\section{PART I OVERVIEW}

In a short lecture note written just months before his death, Joseph Schumpeter [3] claimed that:

...neither the analysis of the economic process - economics - nor the analysis of the political process - political science - is adequate by itself to explain actual sequences of events. This is the reason why so many writers have come to plead for a Political Economy which is to combine both and much besides. The difficulties that beset this line of advance, however, must be clearly understood (p. 193).

The general framework, and the basic methodological assumptions of this Handbook, have a great deal in common with those developed by Schumpeter in this text [3]. As in Schumpeter's text, the analysis guiding the outline of this Handbook is best described as a circular motion, where the purely economic aspects of a society (at least partly) determine central features of the political system and this system, in turn, is a crucial element in explaining the economic outcome.

In Baumol's text [1], the analysis of entrepreneurship and institutions is framed by a historical context. The growth of an entrepreneurial class (a bourgeoisie) is explained by the power struggle between kings and the noble upper classes. In order to raise armies, financially weak rulers were forced to concede more and more property rights to other classes. It gradually became apparent that more economic freedom spurred economic growth, something that gave liberal kingdoms an upper hand. Thus, entrepreneurs' positive and productive response to institutional change created a shift in power, which further reinforced the move towards protection of private property. Baumol's analysis explains the rise of a society where property rights were protected and individuals were given incentives to build private wealth as business owners.

The success of the private enterprise became apparent in the process of industrialization, where private firms grew into large corporations. But what about new small firms, could they stand a chance against these giants? What if the historical success of the individual entrepreneur carried the seed of its own destruction from the very beginning? In the chapter "Crumbling Walls" [2], we meet this central argument of Schumpeter's masterpiece Capitalism, Socialism and Democracy. This is the wellknown prophecy about the mechanization and routinization of the entrepreneurial function and the waning role of the individual entrepreneur. In hindsight, we might doubt the accuracy of the prophecy, but the logic laid out about the walls (institutions) that are crumbling still deserves attention.

Part of the reason why Schumpeter predicted that capitalism was coming to an end was its success over the aristocratic, elite class of rulers. Although this class might have constituted an obstacle in early stages of development, it later came to provide a protective layer against other interests. The new threat did not come from the elite, but from the proletariat, and its political power in a democratic society. Henrekson and Jakobsson [8] provide an analysis where they show that in many respects, Schumpeter's prophecy almost came true in the Swedish welfare state.

The general approach of this Handbook also draws much inspiration from the recent theoretical contributions by Acemoglu and Robinson [6]. Their result called captured 
democracy is highly relevant for our purposes. Democratic institutions may have prevailed on the surface of things but underneath, a former elite can still continue to influence the de facto institutions. This teaches us something very important about inertia in institutional change and why new entrants in the economic market may face severe problems, despite better products and more efficient modes of production.

This line of theorizing also highlights another aspect of entrepreneurship, namely its ability to proactively take part in and change the institutions. To capture some of the implications of this, we have tried to distinguish between institutional changes that are the result of a political process and changes that are more directly instituted by economic interests and individual political entrepreneurs. Since changing the institutional setup can generate large profits for certain groups, we would expect large flows of entrepreneurial talent and energy towards the political arena. This is one of the central arguments in Benson [7]. Another important argument in Benson is that regulation often breeds further regulation, because new rules create opportunities to earn profits by dodging the rules. Thus, politicians find it necessary to remedy loopholes by imposing new legislation. In this process, there is plenty of scope for entrepreneurs to act so as to influence the institutional framework in their favour.

The entrepreneur is explicitly introduced in this analysis in Kirzner [4]. Here, entrepreneurship is defined as being fundamentally about alertness to and discovery of new opportunities, which brings to light a deep-seated contradiction regarding government interventions in the market. Implicit in all such interventions is an assumption that the government can accurately identify and implement the best ways of steering the economy. But, according to Kirzner, this is an entrepreneurial decision, and the market's strength vis-à-vis a central government is to delegate this decision to millions of agents. This delegation makes the market a far superior mechanism for avoiding systematic errors.

Kirzner's approach is seemingly opposite to the Schumpeterian one. In the former, entrepreneurship is about discovering previously unnoticed opportunities and thereby remedying market error, whereas the Schumpeterian view is essentially about innovation. If the Schumpeterian entrepreneur disturbs existing equilibria, the Kirznerian entrepreneur moves the economy towards a state of equilibrium. These two entrepreneurs can be combined to generate a more complete view on the entrepreneurial role of the dynamics and development of an economy. $\mathrm{Yu}$ [5] does exactly this; by using the different functions embodied in the two approaches, he presents an account of economic dynamism via institutional change.

\section{PART II PROPERTY RIGHTS AND ENTREPRENEURSHIP}

The institutions that together provide a secure protection of private property rights are the most prominent by far. There are several reasons for this. First of all, the notion of property rights has an obvious connection to private property and therefore to profits and economic incentives. Second, the notion of property rights can be defined at an abstract level. For instance, by several accounts, taxation should be considered as an infringement of private property. Furthermore, various forms of regulations effectively erect barriers as to how private assets can be used, thereby reducing their market value. Both these circumstances have important implications for entrepreneurship, some of which are the topic of other parts of this Handbook. But the aspect of property rights that is of particular importance in this part is its intimate relation to investment, especially investment in small firms. 
The first paper in this part is a chapter from Hernando de Soto's [9] book the Mystery of Capital. It is best introduced by a quotation:

Capital, like energy, is also a dormant value. Bringing it to life requires us to go beyond looking at our assets as they are to actively thinking about them as they could be...Property is the realm where we identify and explore assets, combine them and link them to other assets. The formal property system is capital's hydroelectric plant. This is the place where capital is born (p. 45 and p. 47, italics in original).

De Soto emphasizes the crucial distinction between assets and capital. Capital is what holds the potential for economic dynamism and growth. Assets, without a system of property rights, he claims, are just dead matter. One of the most important effects of a well-functioning property rights system is that it determines the economic potential of assets; it thus enables the owner to envision ways of using the capital. Entrepreneurial ventures are the obvious vision relevant for our purposes.

Without a well-functioning protection of property rights, not only will many potential entrepreneurs be reluctant to invest, but it also makes predatory forms of entrepreneurship more profitable. If the institutional framework does not channel entrepreneurship in productive ways, these individuals will devote their talent and energy to other things. Hence, poor property rights give more opportunities for various kinds of appropriative entrepreneurship, which further reduces the expected return to investment in productive entrepreneurship. This is modelled in Gonzales [11].

The transition of former socialist economies has provided an opportunity for an empirical evaluation of the consequences of poor property rights. Johnson, McMillan and Woodruff [10] is one of the largest and most ambitious surveys of this kind. They use a questionnaire to survey a large sample of manufacturing firms in five post-communist countries. Their main variable of interest is the extent to which firms reinvest profits. Such reinvestment is expected to be held back in a situation with weak protection of future returns. This conjecture is supported by their empirical analysis. Furthermore, controlling for credit constraints did not change the result. This was interpreted as suggesting that not only are secure property rights necessary, but also sufficient for productive investment.

In empirical work, composite indexes of institutional quality are frequently used. There are often considerable measurement problems when trying to single out the effect of specific institutions. One instance where it has been possible to identify the effect of a single institution is the bankruptcy exemption level. How does the rate of compensation to the lender in case of bankruptcy affect the level of entrepreneurial activity? This is the empirical question raised in the article by Fan and White [12]. Theoretically, a higher exemption rate implies a lower risk for the nascent entrepreneur, which should spur the formation of small businesses. They test this hypothesis by using variations in exemption rates across US states. Their results are consistent with their hypothesis.

\section{PART III TAXATION AND ENTREPRENEURSHIP}

As noted in the previous part, taxation can be subsumed as a special instance of property rights legislation, because taxation directly affects the expected returns of an 
investment. Thus, taxation enters directly as an explanatory variable in the decision to become an entrepreneur. But it also enters indirectly, and in ways that are less visible. One important aspect, which has not been subject to much research, concerns how taxes affect the formation of personal wealth and thus, the ability and willingness to venture into entrepreneurship. Another largely unexplored factor is related to timing and relative tax effects of early and late exit from a venture.

Much research on taxation and entrepreneurship has been done in the tradition of Domar and Musgrave [13]. Their conclusion was that high levels of taxation encourage risk-taking behaviour and, consequently, entrepreneurship. This result is an outcome of the assumption that governments do not only tax profits but also compensate for losses. This effectively reduces the variance in the distribution of possible outcomes, something that encourages risk-taking if risk aversion is assumed. As already discussed by Domar and Musgrave, the assumption of loss compensation is at odds with reality. It is rarely, if ever, the case that entrepreneurs who incur large losses receive direct (symmetric) transfers from the government corresponding to a negative tax. The issue of progressivity is also noteworthy. Domar and Musgrave's result only holds under the assumption of constant marginal taxes. If progressive taxes are imposed, this will remove the symmetry between profit taxation and loss compensation. Regardless of these shortcomings, their analysis has lived on as an influential point of reference in the literature.

Kanbur [14] frames the same analysis in an occupational choice model. Contrary to Domar and Musgrave, in this framework, the risky decision of whether or not to become an entrepreneur is a discrete choice. From this setting, he derives the result that the free market outcome exhibits too much risky behaviour, a result which is sensitive to certain assumptions on risk aversion, but still shows that the implications of taxation on risk taking are by no means self-evident. Here, the normative result is that the government should impose progressive taxes in order to restrain the level of entrepreneurial activity.

Robson and Wren [15] explore the differential impact of marginal and average tax rates on self-employment and salaried employment. Their analysis features another prominent component in the literature on taxation and self-employment, namely that someone who is self-employed has greater opportunities to avoid taxes than a salaried worker. This is a circumstance that fits nicely into the approach of this Handbook. Specifically, it shows that self-employment cannot be uncritically taken as synonymous with productive entrepreneurship. Basically, individuals can enter into self-employment for several reasons, one of them being the opportunity to avoid taxes.

In addition to this, Robson and Wren assume the effort level to be higher in self-employment on the margin. Hence, the entrepreneur faces higher marginal taxes. These two assumptions result in two theoretical predictions: that the self-employment rate varies negatively with marginal taxes and positively with average taxes.

The last theoretical article in this part does not deal with how taxes directly affect entrepreneurship. Keuschnigg and Nielsen [16] instead investigate taxes in relation to venture capital. Venture capital offers a contract that overcomes many of the problems of asymmetric information inherent in new firm start-ups. Moreover, venture capital firms take an active part in the management of the firm. It is this dimension, together with the amount of funding (i.e. entrepreneurial activity), which is the focus of Keuschnigg and Nielsen's analysis. Their main result is that a capital gains tax reduces the amount invested but increases the quality of managerial advice. 
Further, it is found that progressive rather than proportional income taxes distort investment decisions.

There is a large literature which empirically investigates the effects of taxes on selfemployment. Although recent results indicate that the relation is negative, the results are inconclusive and an overall judgment is still premature. The main problem that research has tried to tackle deals with endogeneity. Since the effective tax rate is the result of the decision to enter into entrepreneurship, this is itself obviously not an exogenous determinant of entry.

Time-series methods were the first to be applied to the issue of tax effects on small business creation. In these studies, using aggregate data for marginal tax rates typically circumvents the endogeneity problem. However, in the early studies, the evidence, if at all significant, indicated a negative effect. A recent update of these studies is Bruce and Mohsin [17]. They apply more sophisticated methods of timeseries analysis and do this on a dataset spanning a longer time-period than previous analyses. The strongest result is that the top corporate income tax rate has a negative effect on entrepreneurial activity. Moreover, effects are also found for payroll taxes. Even though these results provide evidence that taxes do affect entrepreneurial decisions, the authors point out that the identified effects are of a small magnitude.

An obvious limitation of time-series methods is the inability to account for the micro level. The study by Parker [18] is an example where binary-decision models are used to analyse cross-section micro-level data. He uses British cross-section data sets to test whether the tax liabilities that are conditional on self-employment affect entrepreneurial entry. However, the study fails to find evidence of tax effects on incentives to become an entrepreneur.

Recently, access to detailed longitudinal data has made it possible to overcome some of the shortcomings of earlier studies. Bruce [19] uses a panel data set from the US Panel Study of Income Dynamics survey to study how differential tax treatment of the self-employed affects decisions to enter or exit self-employment. The strategy for avoiding endogeneity is to use a tax reform as an exogenous variation in marginal tax rates for the self-employed. The results indicate that a lower marginal tax rate for the self-employed (keeping the income tax of employees constant) reduces entrepreneurial activity.

Gentry and Hubbard [20] use the same dataset as Bruce, but instead focus on tax progressivity. Theoretically, we have already seen that increased progressivity should be expected to have a negative effect on self-employment rates. Gentry and Hubbard's results are consistent with this hypothesis; increased convexity in the taxrate reduces entrepreneurial activity. Further, the effects of a reform can be large. An increase in the marginal tax spread between successful and unsuccessful ventures from 2 to 7 percent is associated with a reduction in the probability of entering selfemployment by 9 percent.

In a number of studies, Carroll, Holtz-Eakin, Rider and Rosen investigate the tax-effect on existing small firms. In [21], they analyse the effects on decisions to increase the number of employees. For this purpose, they use a panel of small firms in the US. They have observations before and after a major hike in marginal tax rates, which is used as an exogenous source of variation. The firm's probability of hiring was found to decrease substantially after the reform. Raising the marginal tax rate by 10 percent reduced the probability of hiring by 12 percent. 
This part has dealt with many facets of taxation in relation to entrepreneurship. The main lesson we want to emphasize is that the sheer number of small businesses created is not the only outcome variable of relevance. It is likely to be even more important to look at what types of businesses are created and their prospects for survival and growth. If, for instance, the reason why high tax rates stimulate the creation of new firms is the greater scope for tax evasion, then one must question whether and to what extent these new firms contribute to growth.

\section{PART IV SUBSIDIES TO ENTREPRENEURSHIP}

The selected articles in the next section deal with support and programs designated to entrepreneurship. This part contains articles more generally analysing the consequences of subsidies to lending. A common point of departure for these studies is that the financial market works imperfectly. In the context of entrepreneurship, this usually translates into problems of asymmetric information regarding the abilities of the nascent entrepreneurs, his/her prospects and the risk of the project. Among entrepreneurship scholars, a consensus that small firms and nascent entrepreneurs face financial constraints has gradually emerged. The conclusion that is generally drawn is that something should be done to promote and support the formation of new firms.

The first article in this part, Gale [22], is a quantitative simulation analysis of the effects of government credit subsidies. Substantial crowding-out effects and efficiency losses are found. Furthermore, the results indicate that the major part of the welfare gains accrue to groups which would not have been credit constrained even without the subsidy.

The second paper by DeMeza [23] puts many implicit assumptions on their head. One such conjecture is that more risk-taking in the form of small-business startup is, in a normative sense, a good thing. But deMeza points at two circumstances that lead to excessive risk-taking. Both of these are externalities resulting when the most able individuals venture into self-employment. When this happens, the returns to employment drop, giving more and less able employees an incentive to venture into self-employment. At the same time, the rate of failure of small firms is low as long as only individuals with high abilities are self-employed. This implies a downward pressure on borrowing rates and, consequently, even larger flows of people into selfemployment. From these two factors, it can be deduced that the distribution of talent is sub-optimal. This result questions the received view that the government should provide financial aid to small firms. Instead of a shortage of entrepreneurial start-ups, deMeza argues that too many small firms are started. And, by providing assistance to new firms, the government only makes things worse.

The article by $\mathrm{Li}$ [24] explicitly investigates the effect of various government support schemes. This is done in a model with financial market frictions. One result is that loan guarantees have the most detrimental incentive effects. Loan guarantees give the investor an assurance that the government will step in if the entrepreneur defaults on his loans. This attracts very risky projects. Furthermore, grants given to the entrepreneur at the end of a specified period are found to be the most efficient way of stimulating a specific kind of entrepreneurship. A general result is that all kinds of subsidies result in more investment in new firms but reduced private savings.

Keuschnigg and Nielsen [25] analyse the effect of government subsidies on venture capital. As we have already seen, government support is likely to lead to crowding-out effects. The results in Keuschnigg and Nielsen suggest that these effects 
do not only hurt similar types of financial means, but also other forms such as venture capital finance. They find that subsidizing investment is likely to cause the venture capitalists to cut back on their managerial support, thus increasing the risk of failure. The only kind of support that can be efficiency enhancing is managerial and information services - conditional on the government being a better advisor than the venture capitalist.

A dam is probably a good illustration of a common way of considering financial constraints. According to this metaphor, the dam obstructs and hinders the flow of entrepreneurship and productivity, and the aim of policies is to release this energy. But what if the freed water-reserve were not to flow orderly in one stream? And what if we could only remove the dam piecewise by blowing a hole here and there without knowing the exact consequences? Would not the water then flow in highly unpredictable and uncontrolled ways? We deem that this latter image is more appropriate in the context of entrepreneurship. The articles in this part have presented some advances towards understanding the complexity of financial constraints. The attempt to move away from considering financial constraints as simply an unnatural impediment is, in our view, particularly promising.

\section{PART V ENTREPRENEURSHIP POLICIES}

In recent decades, entrepreneurship and small businesses have loomed large both on the political and the research agenda. Therefore, relevant institutions also include the wealth of policy measures that have been designed and specifically directed toward small firms. A broad division of these programs are financial support schemes, tax breaks and subsidies, advisory services and science parks.

Gilbert, Audretsch and McDougall [26] discuss a number of ways in which recent changes in the industrial and market structure have emphasized the importance of small businesses, and how governments around the world and at different levels have responded to this. On the surface of things, governments scaled down their involvement in markets, primarily through a wave of privatisations beginning in the 1980s. However, the analysis of this paper draws the attention to another interpretation; parallel to the increased importance of the small firm, governments changed the focus of their interventions. In practice, this is reflected in a dramatic increase in programs aimed at small businesses.

The rationale behind such interventions is discussed by Holtz-Eakin [27]. To motivate government intervention from an efficiency perspective, one would have to point at some kind of externalities generated by small firms. In this respect, it is common to refer to the contribution of small firms to innovativeness and renewal at the aggregate level. These are effects that presumably benefit many economic agents but are not internalised at the individual firm level. Another line of argument for special support to small firms has already been discussed, namely their susceptibility to capital-market imperfections.

Overall, Holtz-Eakin deems that the motives discussed for special support to small firms are weak. In addition, we want to emphasize what we consider to be the most critical aspect of such programs, namely the fact that they ultimately hinge on the ability of the government, and the appointed executive agency, to pick the right firms to support. Here, it should be noted that if entrepreneurship is seen as the ability to perceive and be alert to opportunities, this selection process actually means that the government is trying to fill the entrepreneurial function. 
A number of studies have been devised to evaluate the impact of entrepreneurship programs. These studies typically find a positive effect on the supported firms. One such study is Lerner [28] who investigates the effect of the US Small Business Innovation Research Program. He follows a large number of firms over a ten-year period. Some firms in this panel received support in the form of a grant, others were matched firms included as a control group. The firms that participated in a program enjoyed much higher growth rates than did a matching firm without support. Interestingly, the result did not show any correlation between the success rate and the level of support. One interpretation is that the primary benefit of the program was as a "stamp of approval", a kind of certificate signalling the prospects of the firm to other agents.

Wren and Storey [29] look at a different type of support. They use UK data to investigate the effects of subsidised support for marketing, directed toward small firms. They find a large positive effect of the program on survival and employment growth. When dividing the sample into small, medium and large firms, the effect was heavily concentrated to the middle stratum. One way of interpreting this is that too small and too large firms are unable to accommodate the support in a beneficial way. Another suggestive result that emerged was that the kind of firms that were granted support had greater survival but poorer growth prospects than other firms. Even though the exact implications of this are difficult to disentangle, it highlights the crucial fact that the effect of a program will crucially depend on how the support is directed.

A common shortcoming of this kind of studies is that they can only generate knowledge about partial-equilibrium properties. No account is taken of implications for the income side of the government budget, and the possibility of efficiency losses from financing the programs. The studies are equally silent about crowding-out effects on private agents. But most crucial is probably the neglect of the effect of promoting a specific kind of firms on the overall industry structure, and how this feeds back to other firms. Unfortunately, it is very difficult to say anything empirically about the overall outcome in these respects. One exception, however, is Cumming and MacIntosh [30] who rely on a Canadian program to analyse the impact on the supply of venture capital. They find this tax-based program to have severe crowding-out effects on private sources of finance. Crowding-out takes place to such an extent that the overall supply of venture capital in the economy actually declined as an effect of the program.

\section{PART VI POLITICAL ENTREPRENEURSHIP}

Hitherto we have primarily been interested in how various politically determined institutions affect entrepreneurship. In this part and those that follow, we will turn to the opposite causality and study different ways in which entrepreneurship contributes to and transforms the institutional framework. That an entrepreneur has incentives to engage in such activities is easily seen against the background of the directed activities discussed in the previous part. For instance, it can be highly profitable for an entrepreneur to try to influence the programs and tailor the criteria for eligibility to his own needs. In this part, we will see how entrepreneurship is of direct relevance for the study of the political sphere. 
Holcombe [31] introduces the concept of entrepreneurship in politics. A political entrepreneur is someone who, just as in the market place, is alert to, and acts upon, opportunities for profit. Now, there are two types of opportunities. The first is to remove inefficiencies by restructuring government activities. This is the kind of opportunity with the potential of yielding benefits to broad strata of the population. The second kind of opportunity is the (forcible) transfer of wealth from one group to another. These latter, predatory, forms of entrepreneurship tend to be more common in politics than in economic markets. The most important reason for this is the coercive element in politics. Agents do not have the option of not partaking in the game governed by political institutions. Furthermore, citizens that are not active in politics must obey the law, and also those that have not actively resisted a transfer of wealth are affected by it. Thus, predatory political entrepreneurship can be said to have a high leverage and, if successful, it can yield large returns. Thus, in contrast to economic entrepreneurship, political entrepreneurship does not necessarily (or even primarily) contribute to efficiency. Finally, Holcombe also makes the important observation that there will always be opportunities for redistribution in politics, even in an imagined state of equilibrium.

Holcombe's analysis belongs to the Kirznerian tradition, where the entrepreneur's alertness to opportunities is central. Wohlgemuth [32], on the contrary, is an attempt to draw out the implications of a Schumpeterian approach to political entrepreneurship. Two sides of Schumpeter are contrasted. The early Schumpeter saw entry of new actors as the driving force in the innovative process, while the later Schumpeter emphasized the role of the large established firm. Wohlgemuth frames the analysis of the democratic process in terms of Tullock's concept of bidding for (political) monopoly. He does this in order to work out the consequences of various institutional arrangements on political reform and renewal. Renewal is here seen as the result of either of the Schumpeterian processes.

These two articles belong to a rather small literature that tries to capture the effect of some of the more illusive dimensions of entrepreneurship. It has repeatedly been pointed out that entrepreneurship has for a long time been neglected in economic analysis, and that it has just recently made some advance into the mainstream of economic analysis. There is a similar neglect in the analysis of the political sphere. In this part, we include some components that are relevant to such an analysis.

\section{PART VII POLITICAL MARKETS, INTEREST GROUPS AND COALITIONS}

A few words are in order to explain how this part differs from the previous one. Some of the selected articles in this part seemingly move away from the entrepreneur. They do so in the sense that they move away from the entrepreneur qua an individual economic agent. Instead, the focus is here on political coalitions and interest groups. In one respect, this is a distinction between the political process and the institutional set-up. In the previous part, no distinction between these two entities was necessary. In reality, this applies to countries where those in power have much discretionary power. But with respect to well functioning democracies, we believe that the distinction is important to make. Here, the institutional framework exhibits a great deal more inertia, and it evolves through a political process. The political element of entrepreneurship consists of acting through interest groups and changing the political power structure. 
Stigler [33] is a classic exponent of the mechanism behind the influence of economic interests in the political sphere. Bluntly, he presents a hypothesis that has been guiding much subsequent research: "every industry or occupation that has enough political power to utilize the state will seek to control entry" (p. 5). The analysis dissects various ways of accomplishing such control, and why a political majority may accept such legislation. Most important for our purposes is the fact that the analysis brings forth a classic dilemma, namely that those who have benefited and thrived thanks to certain institutions may later act to change the same institutions in order to bar new entrants. Today's successful entrepreneurs may be identical to those who will block new entrants in the future.

A proper understanding of this dilemma necessitates an investigation of how political coalitions are formed. In a setting where government taxation, redistribution and provision of public goods are endogenously determined through a voting process, the two coalitions of voters have traditionally been high- and low-income individuals. Roine [36] shows that in the presence of tax avoidance techniques, another pattern may emerge. If the cost of tax avoidance is sufficiently low, high-income individuals may form a coalition with low-income individuals in support of high taxes. Another instance where the rich might behave in an unexpected way is property rights protection. Sonin [35] analyses a model where the rich prefer poor public protection of property rights, since this allows them to extract rents from other groups while investing in private protection of their own property.

But the government is more than simply a vehicle for redistribution and the carrying out of legislation designed to fill the demands of special interests. More specifically, the government serves an important function as a third party in contract enforcement. Acemoglu and Verdier [34] build on this aspect. Entrepreneurial activity is here dependent on a well-functioning enforcement of property rights, which in their model can only be provided by the government. But an overly extensive government is associated with bureaucratic corruption. One of the contracting parties might find it profitable to bribe an official. These mechanisms have detrimental effects on the number of contracts signed and businesses started.

The spectrum from interest groups to rent seeking and corruption is wide, and we do not want to claim that it is only a question of degree. Rather, these phenomena represent different methods through which economic interests influence politics. Here, in the context of entrepreneurship, it is once more important to note the circularity. How the process of institutional change comes about, i.e. by which method it is materialized is, in turn, dependent on how the existing institutions channel entrepreneurial talent. If it is more profitable to devote energy to bribing officials or forming political alliances, entrepreneurial talent is directed to these areas rather devoted to more socially productive pursuits.

\section{PART VIII INNOVATION AND VESTED INTERESTS}

An important instance of the mechanisms described in the previous section is the introduction of innovation and how this is resisted by some groups. Mokyr [37] analyses this resistance to new innovations in terms of two evolutionary systems, one technical and one politico-social. These two systems develop in tandem, with several points of mutual interaction. Mokyr discusses informally how evolvement in the technological system, through the introduction of new innovations, creates tensions in the other politico-social system. Many individuals find themselves at a disadvantage 
when new innovations are introduced. There are several reasons for this. The first, and foremost, reason is that conversion of capital is seldom costless. This is true with respect to physical capital, but it is probably an even more acute problem when it comes to human capital. Since new innovation almost inevitably involves the reallocation of such resources, many groups normally face (at least) a short-term loss in terms of unemployment or capital obsolescence.

Krusell and Ríos-Rull [38] analyse this logic in a formal model of overlapping generations. Here, investment in technology-specific skills creates vested interests. These coalitions can only be broken with the birth of a new generation. Hence, the introduction of new technology can be stalled for some time. In this framework, they also show that it is possible to have an equilibrium where the political majority shifts between allowing and banning new innovations. In the long run, this creates a cyclical pattern of technological progress in the market and, in the short run, it can be interpreted as a move to a more liberal (or a more conservative) regime.

But, if the new technology increases productivity, why does the political majority not use its power to tax the gains from an improved production process, instead of banning it? This question was first raised by Acemoglu and Robinson [40]. They emphasized that the strength of the affected group must be taken into account. Bellettini and Ottaviano [39] build on this insight and develop a model where the regulation of new technology is determined by lobbying rather than voting.

\section{PART IX ENTREPRENEURSHIP AND SOCIAL MOBILITY}

In parts VII and VIII, we saw how the political sphere acts on and shapes the institutional environment in which entrepreneurs make decisions. One important component of this discussion was the active part that entrepreneurs play in political life. We now turn to how personal wealth may be used to wield political power. With respect to this issue, it is important to consider the great potential to create private wealth through entrepreneurship. Another issue, which we find to be equally important, but that has scarcely been studied, is the fact that this potential for wealth creation is a great threat to incumbent elites. This should make us wary of strategies for taming or restricting the influence of entrepreneurs.

Much economic research has been devoted to understanding the effect of various dimensions of taxation on economic equality. In a quantitative study, Meh [41] replicates a frequent result from such studies, namely that decreased income tax progressivity leads to increases in wealth inequality. However, there is a dramatic change when the entrepreneur is introduced into this analysis. The effect of a tax reform that reduces progressivity now has a negligible effect on inequality. The general equilibrium mechanism behind this result is that higher net income for entrepreneurs translates into more investments. This, in turn, increases wages, which counteracts the effect on the distribution of wealth.

The analysis in Quadrini [42] departs from Panel Study of Income Dynamics data. Two facts emerge from the descriptive statistics: (i) the distribution of wealth is heavily biased towards entrepreneurs; (ii) this is not only due to higher incomes earned by entrepreneurs because entrepreneurs also have a substantially higher wealth-to-income ratio than employees. Quadrini develops a model to account for these facts, where individuals with the potential of becoming entrepreneurs save more as a result of three things. First, these households have an incentive to save in order to raise sufficient funds to realize their business plans. Second, saving is preferred to 
more expensive external financing. And third, there are more precautionary savings among entrepreneurs in order to counteract the greater exposure to risk.

Another result that emerged from Quadrini's empirical analysis was that individuals engaging in entrepreneurial ventures show a higher degree of social mobility. Higher incomes coupled with a greater savings ratio account for this. HoltzEakin, Rosen and Weathers [43] provide some further insights based on the same data source. They conclude that, in general, people engaging in entrepreneurial activities are more socially mobile. But the direction of this mobility varies across income groups. People belonging to low income groups and starting their own business are more likely to end up in a higher social group than their peers, whereas for people in high-income brackets, entrepreneurship makes a fall in relative income more likely.

In this part, we have treated entrepreneurs as synonymous to business-owners. Therefore, it is important to remember that entrepreneurship in a political economy context is a much broader concept. A more comprehensive account of the effect of entrepreneurship on social mobility would not only include income and wealth effects of business ownership, the effects of less productive kinds of entrepreneurship would also be recognized. Even the kind of entrepreneurship which is, from a social perspective, destructive may have a very positive income effect for a subgroup of the population. It is plausible that such accounts would ascribe an even more important role to entrepreneurship in changing the socio-economic structure.

\section{PART $X$ ENTREPRENEURSHIP IN TRANSITION ECONOMIES}

Much of what has been said about the importance of institutions favouring the promotion of productive entrepreneurship is of even greater relevance in the context of transition economies. The legacy of socialist institutions continues to influence the environment in these countries. This increases the variance in institutional quality across these countries and regions within them. From an analytic point of view, this makes transition economies especially interesting to study. This environment also highlights another issue, namely whether and in what way entrepreneurs can contribute to the transformation of the institutional framework.

Entrepreneurs face special problems in transition economies. These problems fall into two categories: institutions that impede entrepreneurs and the lack of supporting institutions. Corruption among officials, long and bureaucratic processes of applications and certification for new firms and harassment from large, former state-owned firms belong to the former category. Low-quality bank procedures and poor enforcement of contracts are the most serious items in the second category. Chilosi [45] discusses many of these problems in detail. He also points to the danger of equating small-firm creation with productive entrepreneurship. Institutional quality in transition economies makes these countries more susceptible to other, lessproductive, forms of entrepreneurship.

McMillan and Woodruff [44] examine how entrepreneurs facing deficient or missing institutions manage to form strategies to overcome these problems. They stress the importance of close relations and repeated interaction among business partners. In the context of a transition economy, cooperation is facilitated by high search costs for alternative partners, geographical proximity and close social networks implying a high cost of malfeasance. But, at the same time, it is made more difficult by competition for scarce credit and a high discount rate due to high interest rates and large current profits. As pointed out in the article, these compensating arrangements 
can only help firms up to a certain size; growth beyond this point requires wellfunctioning formal institutions.

Smallbone and Welter [46] discuss the role of the government, and how policies in transition economies can be designed so as to promote entrepreneurship. This is done by presenting results from surveys of business owners' own opinions about the role of the government and what problems regarding institutions are the most urgent. They conclude that the government has an important role to play, but that this role looks different depending on which stage of transition the country has reached.

\section{PART XI ENTREPRENEURSHIP IN THE WELFARE STATE}

The last part is, as the previous one, devoted to a whole set of institutions, more precisely the kind of institutions comprising the welfare state. Prominent features of such states are: extensive measures of redistribution, public provision of key service sectors such as health care and education and a comprehensive social-security system. Taken together, the institutions in place to achieve these goals constitute a very special context for the entrepreneur to act within.

Sinn [47] builds on the idea that the institutions of the welfare state provide a kind of insurance. Social insurance, understood in a broad sense incorporating all types of welfare arrangements and redistributive schemes, allows the government to share part of the entrepreneur's gains as well as his or her losses. Hence, they have the effect of decreasing the variance of peoples' living standards, irrespective of their success or failure as entrepreneurs or employees. If people are assumed to be risk averse, this should translate into more risk-taking behaviour. Thus, the conclusion of Sinn's analysis is that welfare state institutions are expected to promote entrepreneurship.

Explicitly arguing against Sinn, Ilmakunnas and Kanniainen [48] point to the circumstance that the welfare state insures entrepreneurship and labour risks differently. In particular, since many welfare schemes are tied to employment, this increases the opportunity cost of entrepreneurial venturing. In a formal occupational choice model, they show that welfare institutions weaken the incentives to become an entrepreneur. Empirical evidence consistent with this proposition is also presented.

Henrekson [49] provides a comprehensive survey of the welfare state institutions that are most pertinent with respect to entrepreneurship. The incentive effects of taxation, redistribution, government production of major services and other key dimensions of the welfare state are examined in detail. In the context of Sweden, it is also shown that the empirical evidence is broadly consistent with what is predicted by theory.

\section{CONCLUDING REMARKS}

As we have seen, it is no coincidence that core theoretical inquiries into entrepreneurship have put the entrepreneur in a political economy context. However, this tendency has been lost in most of the recent literature, where it is just assumed that entrepreneurship is beneficial for society, while the risk of rent-seeking and political entrepreneurship as an effect of inappropriate institutions is overlooked. In this survey, we have ascribed vital functions of the capitalist economy to the 
productive entrepreneur. But, at the same time, we hope that the articles in this Handbook taken as a whole show that the social value of entrepreneurship should be evaluated as it is realized. Entrepreneurship cannot uncritically be taken as the answer to the quest for economic growth.

We have discussed three major aspects of entrepreneurship that are important from a political economy perspective. First, entrepreneurship, regarded as a resource, is in essence dynamic. It is dynamic in the sense that it will adjust to the politically determined institutional framework within which it acts. Under propitious circumstances, it can be a powerful engine of growth, but it can also be channelled in unproductive and destructive directions. Thus, it is important to discern which institutions are particularly important and what are the effects of these pertinent institutions on entrepreneurship.

Second, entrepreneurship enters directly into the political system. The close connection to property rights constitutes a link between entrepreneurship and private versus public ownership and redistribution. Under unfavourable institutional circumstances, rent-seeking and predatory entrepreneurship via the political system offer greater profit opportunities than the market. In addition, entrepreneurial rents provide opportunities for the individual to amass great private wealth. The question then arises of whether and how this wealth translates into political power.

Third, a political economy approach is important in order to understand how the political system shapes the institutional setup. How does entrepreneurship enter in the formation of different political coalitions? How do vested interests and the current distribution of power influence the scope for innovation and productive entrepreneurship?

\section{WORKS SELECTED}

[1] William J. Baumol (2002), 'Independent Innovation in History: Productive Entrepreneurship and the Rule of Law', in W. J. Baumol, The Free-Market Innovation Machine, Princeton and Oxford: Princeton University Press, Chapter 5, 55-72

[2] Joseph A. Schumpeter (1942), 'Crumbling Walls’, in J. A. Schumpeter, Capitalism, Socialism and Democracy, New York: George Allen \& Unwin, Chapter XII, 131-142

[3] Joseph A. Schumpeter (1983), ‘American Institutions and Economic Progress’, Zeitschrift für die gesamte Staatswissenschaft, 139(2), 191-196

[4] Israel M. Kirzner (1985), 'The Primacy of Entrepreneurial Discovery’, in I. M. Kirzner, Discovery and the Capital Process, Chicago and London: University of Chicago Press, Chapter 2, 55-72

[5] Tony Fu-Lai Yu (2001), 'An Entrepreneurial Perspective of Institutional Change’, Constitutional Political Economy, 12(3), 217-236

[6] Daron Acemoglu and James A. Robinson (2006), 'De Facto Political Power and Institutional Persistence', American Economic Review, 96(2), 325-330

[7] Bruce L. Benson (2004), 'Opportunities Forgone: The Unmeasurable Costs of Regulation', Journal of Private Enterprise, 19(2), 1-25

[8] Magnus Henrekson and Ulf Jakobsson (2001), 'Where Schumpeter was Nearly Right - The Swedish Model and Capitalism, Socialism and Democracy', Journal of Evolutionary Economics, 11(3), 331-358 
[9] Hernando de Soto (2000), 'The Mystery of Capital', in H. de Soto, The Mystery of Capital : why Capitalism Triumphs in the West and Fails Everywhere else, London: Bantam, Chapter 3, 39-67

[10] Simon Johnson, John McMillan and Christopher Woodruff (2002), 'Property Rights and Finance', American Economic Review, 92(5), 1335-1356

[11] Francisco M. Gonzalez (2005), 'Insecure Property and Technological Backwardness’, Economic Journal, 115(505), 703-721

[12] Wei Fan and Michelle J. White (2003), 'Personal Bankruptcy and the Level of Entrepreneurial Activity’, Journal of Law and Economics, 46(2), 543-567

[13] Evsey D. Domar and Richard A. Musgrave (1944), 'Proportional Income Taxation and RiskTaking', Quarterly Journal of Economics, 58(3), 388-422

[14] Ravi S. M. Kanbur (1980), 'Risk Taking and Taxation: An Alternative Perspective’, Journal of Public Economics, 15(2), 163-184

[15] Martin T. Robson and Colin Wren (1999), 'Marginal and Average Tax Rates and the Incentive for Self-Employment', Southern Economic Journal, 65(4), 757-773

[16] Christian Keuschnigg and Søren Bo Nielsen (2002), 'Tax Policy, Venture Capital and Entrepreneurship’, Journal of Public Economics, 87(1), 175-203

[17] Donald Bruce and Mohammed Mohsin (2006), 'Tax Policy and Entrepreneurship: New Time Series Evidence’, Small Business Economics, 26(5), 409-425.

[18] Donald Bruce (2000), 'Effects of the United States Tax System on Transitions into Selfemployment’, Labour Economics, 7(5), 545-574

[19] Simon C. Parker (2003), ‘Does Tax Evasion Affect Occupational Choice?’, Oxford Bulletin of Economics and Statistics, 65(3), 379-394

[20] William M. Gentry and R. Glenn Hubbard (2000), ‘Tax Policy and Entrepreneurial Entry’, American Economic Review, 90(2), 283-287

[21] Robert Carroll, Douglas Holtz-Eakin, Mark Rider and Harvey S. Rosen (2000), 'Income Taxes and Entrepreneurs' Use of Labour', Journal of Labor Economics, 18(2), 324-351

[22] William G. Gale (1991), 'Economic Effects of Federal Credit Programs', American Economic Review, 81(1), 133-152

[23] David de Meza (2002), 'Overlending?’, Economic Journal, 112(477), F17-31

[24] Christian Keuschnigg and Søren Bo Nielsen (2001), 'Public Policy for Venture Capital', International Tax and Public Finance, 8(4), 557-572

[25] Wenli Li (1998), 'Government Loan, Guarantee, and Grant Programs: An Evaluation’, Federal Reserve Bank of Richmond Economic Quarterly, 84(4), 25-51

[26] Brett Anitra Gilbert, David B. Audretsch and Patricia P. McDougall (2004), 'The Emergence of Entrepreneurship Policy’, Small Business Economics, 22(3/4), 313-323

[27] Douglas Holtz-Eakin (2000), 'Public Policy Toward Entrepreneurship’, Small Business Economics, 15(4), 283-291

[28] Josh Lerner (1999), 'The Government as Venture Capitalist: The Long-run Effects of the SBIR Program', Journal of Business, 72(3), 285-297

[29] Colin Wren and David J. Storey (2002), 'Evaluating the Effect of Soft Business Support upon Small Firm Performance’, Oxford Economic Papers, 54(2), 334-365

[30] Douglas J. Cumming and Jeffrey G. MacIntosh (2006), 'Crowding out Private Equity: Canadian Evidence’, Journal of Business Venturing, 21(5), 569-609

[31] Randall G. Holcombe (2002), 'Political Entrepreneurship and the Democratic Allocation of Resources', Review of Austrian Economics, 15(2/3), 143-159

[32] Michael Wohlgemuth (2000), 'Political Entrepreneurship and Bidding for Political Monopoly’, Journal of Evolutionary Economics, 10(3), 273-295 
[33] George J. Stigler (1971), ‘The Theory of Economic Regulation’, Bell Journal of Economics and Management Science, 2(1), 3-21

[34] Daron Acemoglu and Thierry Verdier (1998), 'Property Rights, Corruption and the Allocation of Talent: a General Equilibrium Approach’, Economic Journal, 108(405), 1381-1403

[35] Konstantin Sonin (2003), 'Why the Rich may Favor Poor Protection of Property Rights', Journal of Comparative Economics, 31(4), 715-731

[36] Jesper Roine (2006), 'The Political Economics of not Paying Taxes', Public Choice, 126(1/2), 107-134

[37] Joel Mokyr (1999), 'Innovation and its Enemies: The Economic and Political Roots of Technological Inertia’, in M. Olson and S. Kähkönen (eds.), A Not so Dismal Science, Oxford: Oxford University Press, Chapter 2, 61-92

[38] Per Krusell and José-Victor Ríos-Rull (2002), ‘Politico-Economic Transition’, Review of Economic Design, 7(3), 309-329

[39] Giorgio Bellettini and Gianmarco I. P. Ottaviano (2005), 'Special Interests and Technological Change', Review of Economic Studies, 72(1), 43-56

[40] Daron Acemoglu and James A. Robinson (2000), 'Political Losers and Barriers to Economic Development', American Economic Review, 90(2), 126-130

[41] Césaire A. Meh (2005), 'Entrepreneurship, Inequality and Taxation’, Review of Economic Dynamics, 8(3), 688-719

[42] Vincenzo Quadrini (2000), ‘Entrepreneurship, Saving and Social Mobility’, Review of Economic Dynamics, 3(1), 1-40

[43] Douglas Holtz-Eakin, Harvey S. Rosen and Robert Weathers (2000), 'Horatio Alger Meets the Mobility Tables', Small Business Economics, 14(4), 243-274

[44] John McMillan and Christopher Woodruff (2002), 'The Central Role of Entrepreneurs in Transition Economies’, Journal of Economic Perspectives, 16(3), 153-170

[45] Alberto Chilosil (2001), 'Entrepreneurship and Transition’, MOCT-MOST: Economic Policy in Transitional Economies, 11(4), 327-357

[46] David Smallbone and Friederike Welter (2001), 'The Role of Government in SME Development in Transition Economies’, International Small Business Journal, 19(4), 63-77

[47] Hans-Werner Sinn (1996), 'Social Insurance, Incentives and Risk-Taking', International Tax and Public Finance, 3(3), 259-280

[48] Pekka Illmakunnas and Vesa Kanniainen (2001), 'Entrepreneurship, Economic Risks, and Risk-Insurance in the Welfare State’, German Economic Review, 2(3), 195-218

[49] Magnus Henrekson (2005), 'Entrepreneurship: A Weak Link in the Welfare State', Industrial and Corporate Change, 13(3), 437-467 